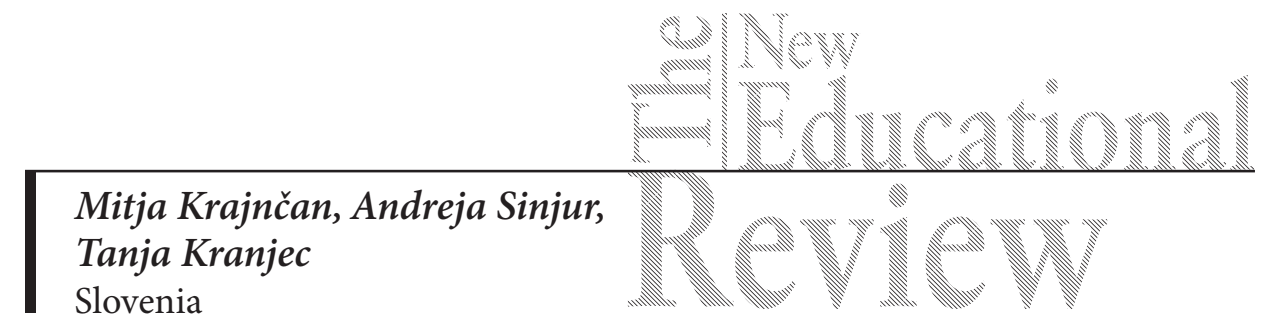

\title{
The Existing Level of Social Competence of Children with Special Needs from the Teacher's Point of View
}

DOI: $10.15804 /$ tner.2015.40.2.22

\begin{abstract}
The development of social competence is reflected in the individual's potential for constructive cooperation and behavior in social situations, in the possibility of establishing interpersonal relationships and understanding different viewpoints and in the capability of to tolerance and compassion. The purpose of this research paper is to compare teachers' opinions on attained social competence of pupils with special needs and other pupils. A questionnaire for teachers was adapted. Pupils with special needs were slightly better at accepting diversity and difference and demonstrated a higher level of politeness than other pupils.
\end{abstract}

Keywords: social competence, relations, pupils with special needs, pupils, teachers

\section{Introduction}

Social competence represents a comprehensive ability of the individual, reflected in effective ways of coping with the requirements imposed by the specific social environment and successful coping with differences and conflicts between social and individual relevant objectives (Oppenheimer, 1989). It includes a fixed repertoire of social competence which has cognitive dimensions (assessment of the social experience, judging the correct and incorrect actions, the ability to identify possible solutions to conflict situations and anticipating their consequences, understanding other people's mental states), the emotional dimension (empathy, ability to put oneself in the position of others in order to understand their feelings, as well as their ways of solving problems, understanding and expressing one's own feelings, accepting other perspectives - identifying expectations, desires, interests 
and intentions of others and assessing the social situation in the light thereof), and behavioral dimensions (actual behavior of an individual in social conflicts, e.g. a viable solution of interpersonal conflict). The second element of social competence is the appropriate level of self-evaluation (e.g. a person believing in his/ her own value, the ability to achieve the desired results, etc.) (Ford, 1985). Social competence relates to skills that are connected to an individual's involvement in social situations. Therefore, the individual has the option to gain skills in this area in every pertaining formal as well as informal form. Both are obtained from birth onwards, but education received from parents or teachers with various forms of social learning is highly important.

Among the general objectives of elementary education (Article 2 of the Law on Changes and Amendments to the Law on Elementary Schools, 2007) it is also possible to find the matter of social competence. This implies that the development of social competence is integrated into the objectives of elementary education, which means that at the end of elementary education individuals are expected to master certain skills in this area. Teachers can develop pupils' social competence through various forms of work (e.g. through the learning of appropriate communication and reaction patterns, by enabling pupils to use role-play in accepting diversity and practicing the displays of emotion), but pupils can also acquire these in various extra-curricular activities, class hours, by voluntary work, etc. Thus, what is of the greatest significance is the development of social competence by parents with (in)appropriate means of education, school, environment surrounding the individual and peers as well.

\section{Pupils with Special Needs and Social Competence}

Pupils with special needs (children with intellectual disabilities, blind and visually impaired children, deaf and hard of hearing children, children with speech and language disorders, physically challenged children, children with long-term sickness, children with deficits in specific areas of learning, children with autistic disorders, children with emotional and behavioral disorders) should receive special attention in schools. When dealing with pupils with special needs we should focus on: (1) a comprehensive and complex approach and (2) detection and identification of pupils' skills (strengths, interests, talents). Pupils with special needs may show lower social competence. Congruent with the concept of the study "Learning difficulties in elementary school", Magajna (2008) points out that these children face difficulties in: communication; planning of activities, 
organization of ideas and materials; use of non-verbal forms of communication; demonstrating low achievement motivation (lesser self-efficacy), visible in negative, inappropriate attitudes and expectations; controlling despondency (depression); abandoning activities and contacts with peers and having problems in the field of social inclusion.

\section{Research Problem}

At elementary schools there are individuals who show low social competence. There is increasing dependency of pupils, inability to work with others, intolerance to the individual and to work, etc. The focus is increasingly put on the individual's egoism. This is notable both with pupils with special needs, as well as other pupils. The extent to which teachers perceive the presence of social competence in these pupils in primary schools will be presented.

\section{Research Focus}

The aim of this study was to compare teachers' opinions on attained social competence of pupils with special needs and other pupils. Therefore, we drew up the following hypotheses:

H1: Teachers believe that all pupils show a low level of development of individual social competence.

H2: Teachers believe that pupils with special needs show a lower level of development of individual social competence than other pupils in:

- recognizing their own emotions and the ability to put oneself in the place of another person

- independence and responsible behavior within a group

- development of closeness, feelings of trust, security and belonging

- acceptance of diversity and differences

\section{Research Methodology}

\section{General Background of Research}

A questionnaire for teachers was adapted. The data were analyzed in comparative and quantitative manners. The descriptive (narrative) and explicative (causal) non-experimental methods of empirical research were used. The descriptive method was used to describe the state of social competence in schools while the explicative method served for the search of the causes and consequences of such a situation. 


\section{Research Sample}

The sample consisted of elementary teachers from different subject areas. The questionnaire was completed by 69 teachers. 30 of them were class teachers (43.5\%), 7 teachers originated from various fields of social sciences (geography, history, ethics and civics), with an equal number of teachers in the field of counseling and additional learning assistance $(10.1 \%)$, as well as 8 teachers working in the field of natural sciences (mathematics, science and engineering, biology, chemistry, physics) (11.6\%), 9 teachers (12.2\%) from the field of visual arts education and music education, 6 teachers (8.1\%) from the field of linguistics (Slovenian, English, German) and 2 teachers (2.7\%) active in after-school activities and the library. All of the teachers did not answer all of the questions as will become evident in the further analysis of the data.

\section{Instrument and Procedures}

A questionnaire for teachers was adapted. It was based on the Social Learning program, which is implemented as a special educational activity for a targeted educational program with lower educational standards (www.zrss.si/ doc/210911085601_pp_nis_socialno_ucenje.doc, retrieved 8/3/2012). Therefore, the validity of the questionnaire was ensured. The questionnaire included claims relating to the development of individual social competence of pupils. 4 questions of a three-level scale were used. De Vaus (2001, p. 53) claims that "a valid measure is one which measures what it is intended to measure." To ensure the efficient collection of valid and reliable data, a pilot study was necessary in order to identify possible shortcomings of the instrument. Therefore, a preliminary form of the questionnaire was provided. Reliability and objectivity of the questionnaire was ensured by providing detailed instructions and unequivocal specific questions. The calculation of Cronbach's coefficient $(\alpha=0.906)$ showed that the questionnaire proved a high degree of reliability. Questionnaires were submitted online.

\section{Data Analyses}

Data were processed and analyzed with the use of SPSS version 14.0 software. The results are presented both in a tabular form as well as descriptively. Since different hypotheses were verified, various tests were used for that purpose:

- The independent-samples T-Test (for the development of individual social competence in pupils with special needs)

- Mann-Whitney U test (to evaluate the arguments where the assumption of the equality of variances was not confirmed. 


\section{Research Results}

Table 1. Agreeing on the development of identifying one's own emotions and the ability of empathy among pupils with special needs and other pupils

\begin{tabular}{|c|c|c|c|c|c|c|c|c|c|}
\hline \multicolumn{2}{|c|}{$\begin{array}{l}\text { Identifying one's own emotions } \\
\text { and the capability of empathy }\end{array}$} & \multirow[t]{2}{*}{$\mathbf{n}$} & \multirow[t]{2}{*}{ M } & \multirow[t]{2}{*}{$S$} & \multicolumn{2}{|c|}{$\begin{array}{l}\text { Levene's Test } \\
\text { for Equality of } \\
\text { Variances }\end{array}$} & \multicolumn{3}{|c|}{$\begin{array}{l}\text { T-test for Equality } \\
\text { of Means }\end{array}$} \\
\hline & & & & & $\mathrm{F}$ & $P$ & $t$ & $\mathrm{~g}$ & $2 \mathrm{P}$ \\
\hline \multirow[b]{2}{*}{$\begin{array}{l}\text { They know how to com- } \\
\text { fort their peers who are } \\
\text { upset or not feeling well }\end{array}$} & pupils & 69 & 1.900 & 0.458 & \multirow[b]{2}{*}{2.943} & \multirow[b]{2}{*}{0.089} & \multirow[b]{2}{*}{-1.223} & \multirow[b]{2}{*}{134} & \multirow[b]{2}{*}{0.224} \\
\hline & $\begin{array}{l}\text { pupils } \\
\text { with } \\
\text { SEN }\end{array}$ & 67 & 2.015 & 0.639 & & & & & \\
\hline \multirow[b]{2}{*}{$\begin{array}{l}\text { They can find help } \\
\text { for their peers when } \\
\text { needed }\end{array}$} & pupils & 68 & 1.779 & 0.418 & \multirow[b]{2}{*}{12.438} & \multirow[b]{2}{*}{0.001} & \multirow[b]{2}{*}{1} & \multirow[b]{2}{*}{1} & \multirow[b]{2}{*}{ I } \\
\hline & $\begin{array}{l}\text { pupils } \\
\text { with } \\
\text { SEN }\end{array}$ & 67 & 2.239 & 0.630 & & & & & \\
\hline \multirow[b]{2}{*}{$\begin{array}{l}\text { They know how to } \\
\text { help their peers when } \\
\text { needed }\end{array}$} & pupils & 67 & 1.850 & 0.530 & \multirow[b]{2}{*}{2.012} & \multirow[b]{2}{*}{0.158} & \multirow[b]{2}{*}{-2.832} & \multirow[b]{2}{*}{130} & \multirow[b]{2}{*}{0.005} \\
\hline & $\begin{array}{l}\text { pupils } \\
\text { with } \\
\text { SEN } \\
\end{array}$ & 65 & 2.139 & 0.634 & & & & & \\
\hline \multirow{2}{*}{$\begin{array}{l}\text { They have the capabil- } \\
\text { ity of empathy }\end{array}$} & pupils & 66 & 1.985 & 0.568 & \multirow{2}{*}{3.803} & \multirow{2}{*}{0.053} & \multirow{2}{*}{-1.289} & \multirow{2}{*}{130} & \multirow{2}{*}{0.200} \\
\hline & pupils & 66 & 2.121 & 0.645 & & & & & \\
\hline
\end{tabular}

( $1=$ I strongly agree, $2=$ I agree, $3=$ = strongly disagree)

Table 2. The Mann-Whitney $U$ test on the development of identifying one's own emotions and the capability of empathy among pupils with special needs and other pupils

\begin{tabular}{cc}
\hline Statement & Mann-Whitney U test results \\
\hline They can find help for their peers when needed & $\mathrm{U}=1440.000,2 \mathrm{P}=0.000$ \\
\hline
\end{tabular}

In regard to the statement They know how to comfort their peers who are upset or not feeling well the teachers expressed stronger agreement when dealing with other pupils $(\mathrm{M}=1.900)$ than was the case with the pupils with special needs $(\mathrm{M}=2.015)$. The assumption of Equal Variances for this claim $(\mathrm{F}=2.943$, $\mathrm{P}=0.089$ ) was confirmed. The teachers estimated that there was no statistically 
significant difference $(\mathrm{t}=-1.223, \mathrm{~g}=134,2 \mathrm{P}=0.224)$ in the assessment of these arguments between the pupils with special needs and other pupils.

The assumption of Equal Variances for the statement They can find help for their peers when needed ( $\mathrm{F}=12.438, \mathrm{P}=0.001)$ was not confirmed. Mann-Whitney test showed a statistically significant difference between the pupils with special needs and other pupils. The teachers expressed stronger agreement with the statement when dealing with other pupils $(M=1.779)$ than was the case with the pupils with special needs $(\mathrm{M}=2.239)$.

In the case of the statement They know how to help their peers when needed the teachers believed that other pupils could better help their peers $(M=1.850)$ when in need, than the pupils with special needs $(\mathrm{M}=2.139)$. The assumption of Equal Variances for the statement $(\mathrm{F}=2.012, \mathrm{P}=0.158)$ was confirmed. The result of $\mathrm{t}$-test $(\mathrm{t}=-2.832, \mathrm{~g}=130,2 \mathrm{P}=0.005)$ shows that between the two groups there is a statistically significant difference, suggesting that the teachers estimate that there are differences in terms of how able the other pupils are to help their peers when needed. According to the teachers, the pupils with special needs are supposed to have more problems in this regard.

Regarding the statement They have the capability of empathy, the teachers again expressed weaker agreement with the statement referring to the pupils with special needs $(M=2.121)$, when compared with other pupils $(M=1.985)$. Dispersion of the teachers' responses about other pupils $(s=0.568)$ is lower than in the case of the answers concerning the pupils with special needs $(s=0.645)$. The assumption of the homogeneity of variances for the statement $(\mathrm{F}=3.803, \mathrm{P}=0.053)$ was confirmed. Between the two groups, there are no statistically significant differences $(t=-1.289, g=130,2 P=0.200)$, thus the teachers estimated that there were no differences regarding the capability of empathy.

The hypothesis stating that the teachers consider other pupils show a low level of the development of social competence can be confirmed by this social competence, as the ratings given by the teachers to other pupils were rather low.

According to the teachers' answers in the evaluation of recognizing pupils' own emotions and the capability of empathy, we can confirm the hypothesis that the teachers consider the pupils with special needs as showing a lower level of social competence than other pupils. This was also confirmed by the theoretical part. Within the given statements, two statistically significant differences appeared, suggesting that the teachers perceive certain differences between other pupils and the pupils with special needs, particularly regarding the statements about finding help and assisting their peers. 
Table 3. Agreeing on the development of independence and responsible behavior within the group among pupils with special needs and other pupils

\begin{tabular}{|c|c|c|c|c|c|c|c|c|}
\hline \multirow[t]{2}{*}{$\begin{array}{l}\text { Independence and respon- } \\
\text { sible behavior within a group }\end{array}$} & \multirow[t]{2}{*}{$\mathrm{n}$} & \multirow[t]{2}{*}{$\mathbf{M}$} & \multirow[t]{2}{*}{$S$} & \multicolumn{2}{|c|}{$\begin{array}{c}\text { Levene's Test } \\
\text { for Equality of } \\
\text { Variances } \\
\end{array}$} & \multicolumn{3}{|c|}{$\begin{array}{l}\text { T-test for Equality of } \\
\text { Means }\end{array}$} \\
\hline & & & & $F$ & $\mathrm{P}$ & $t$ & g & $2 P$ \\
\hline \multirow{2}{*}{$\begin{array}{l}\text { They are able to } \\
\text { participate within } \\
\text { the group }\end{array}$} & 67 & 1.672 & 0.504 & \multirow[b]{2}{*}{0.334} & \multirow[b]{2}{*}{0.565} & \multirow[b]{2}{*}{-5.691} & \multirow[b]{2}{*}{132} & \multirow[b]{2}{*}{0.000} \\
\hline & 67 & 2.194 & 0.557 & & & & & \\
\hline \multirow{2}{*}{$\begin{array}{l}\text { They conscien- } \\
\text { tiously carry out } \\
\text { their tasks within } \\
\text { the group. }\end{array}$} & 68 & 1.838 & 0.536 & \multirow[b]{2}{*}{8.237} & \multirow[b]{2}{*}{0.005} & \multirow[b]{2}{*}{1} & \multirow[b]{2}{*}{ I } & \multirow[b]{2}{*}{1} \\
\hline & 66 & 2.349 & 0.620 & & & & & \\
\hline
\end{tabular}

Table 4. Mann-Whitney $U$ test for the development of independence and responsible behavior within the group among pupils with special needs and other pupils.

\begin{tabular}{lc}
\hline Statement & Mann-Whitney U test results \\
\hline $\begin{array}{l}\text { They conscientiously carry out their tasks } \\
\text { within the group. }\end{array}$ & $\mathrm{U}=1310.500,2 \mathrm{P}=0.000$ \\
\hline
\end{tabular}

The results show that there are significant statistical differences in both statements between other pupils and the pupils with special needs in terms of independence and responsible behavior within the group, at the level of statistical significance $2 \mathrm{P}=0.000$.

Regarding the statement They are able to participate within a group, the teachers gave other pupils the rating of $M=1.672$, which represents a relatively high rate of agreement with this statement in the case of other pupils. The pupils with special needs were given a lower score $(\mathrm{M}=2.194)$. The assumption of homogeneity of variances for the claim $(\mathrm{F}=0.334, \mathrm{P}=0.565)$ was confirmed. Between the two groups, there was a statistically significant difference $(t=-5.691, g=132$, $2 \mathrm{P}=0.000$ ), which means that the teachers believe that the pupils with special needs have greater difficulties when participating within the group.

Similar results were shown regarding the statement They conscientiously carry out their tasks within the group. The teachers gave other pupils a higher score $(\mathrm{M}=1.838)$ than the pupils with special needs $(\mathrm{M}=2.349)$. The assumption of the homogeneity of variances for the claim $(\mathrm{F}=8.237, \mathrm{P}=0.005)$ was not confirmed. The Mann-Whitney U test $(\mathrm{F}=1310.500,2 \mathrm{P}=0.000)$ showed that there is 
a statistically significant difference between the given groups, which means that the teachers believe the pupils with special needs have greater difficulties with the performance of certain tasks within the group.

The hypothesis that the pupils with special needs show a lower level of development of social competence than other pupils in assessing the independence and responsible behavior within the group was confirmed, since in both statements a higher level of disagreement was evident for the pupils with special need, when compared to the other pupils. Within the frame of the given statements, a statistically significant difference was also demonstrated, suggesting that the teachers perceive certain differences between other pupils and the pupils with special needs in the area of independence and responsibility. What was quite obvious were also the low scores when assessing the presence of specific social competence among other pupils, thus the hypothesis that teachers consider that other pupils have a low level of development of social competence was confirmed.

Table 5. Agreeing on the capability of closeness, feelings of trust, security, feelings of belonging among pupils with special needs and other pupils

\begin{tabular}{|c|c|c|c|c|c|c|c|c|c|}
\hline \multirow{2}{*}{\multicolumn{2}{|c|}{$\begin{array}{l}\text { Development of closeness, feelings } \\
\text { of trust, security, feelings of } \\
\text { belonging }\end{array}$}} & \multirow[t]{2}{*}{$\mathbf{n}$} & \multirow[t]{2}{*}{$\mathbf{M}$} & \multirow[t]{2}{*}{$S$} & \multicolumn{2}{|c|}{$\begin{array}{l}\text { Levene's Test } \\
\text { for Equality } \\
\text { of Variances }\end{array}$} & \multicolumn{3}{|c|}{$\begin{array}{l}\text { T-test for Equality } \\
\text { of Means }\end{array}$} \\
\hline & & & & & $\mathrm{F}$ & $\mathrm{P}$ & $t$ & g & $2 \mathrm{P}$ \\
\hline \multirow{2}{*}{$\begin{array}{l}\text { They are able to recog- } \\
\text { nize mutual similarities } \\
\text { and differences with } \\
\text { their peers. }\end{array}$} & pupils & 66 & 1.833 & 0.450 & \multirow[b]{2}{*}{8.375} & \multirow[b]{2}{*}{0.004} & \multirow[b]{2}{*}{ I } & \multirow[b]{2}{*}{ I } & \multirow[b]{2}{*}{1} \\
\hline & $\begin{array}{l}\text { pupils } \\
\text { with SEN }\end{array}$ & 66 & 2.227 & 0.602 & & & & & \\
\hline \multirow{2}{*}{$\begin{array}{l}\text { They cultivate healthy } \\
\text { interpersonal relation- } \\
\text { ships. }\end{array}$} & pupils & 68 & 2.029 & 0.488 & \multirow[b]{2}{*}{1.106} & \multirow[b]{2}{*}{0.295} & \multirow[b]{2}{*}{-0.708} & \multirow[b]{2}{*}{132} & \multirow[b]{2}{*}{0.480} \\
\hline & $\begin{array}{l}\text { pupils } \\
\text { with SEN }\end{array}$ & 66 & 2.091 & 0.518 & & & & & \\
\hline
\end{tabular}

(1=I strongly agree, $\quad 2=I$ agree,$\quad 3=I$ strongly disagree)

Table 6. Mann-Whitney $\mathrm{U}$ test for the development of closeness, feelings of trust, security, feelings of belonging among pupils with special needs and other pupils

\begin{tabular}{lc}
\hline Statement & Mann-Whitney U test results \\
\hline $\begin{array}{l}\text { They are able to recognize mutual similarities } \\
\text { and differences with their peers. }\end{array}$ & $\mathrm{U}=1450.500,2 \mathrm{P}=0.000$ \\
\hline
\end{tabular}

In the case of the statement They are able to recognize mutual similarities and differences with their peers, the assumption of the homogeneity of statement variances $(\mathrm{F}=8.375, \mathrm{P}=0.004)$ was not confirmed. The Mann-Whitney $\mathrm{U}$ test showed 
a statistically significant difference between the pupils with special needs and other pupils $(2 \mathrm{P}=0.000)$. The teachers rated the other pupils with $\mathrm{M}=1.833$, while the pupils with special needs received a lower score, i.e. there was a higher disagreement with the given statement $(\mathrm{M}=2.227)$.

The assumption of the homogeneity of variances regarding the statement They cultivate healthy interpersonal relationships $(\mathrm{F}=1.106, \mathrm{P}=0.295)$ was confirmed. Both values of arithmetic means were similar, as the value for other pupils was $M=2.029$, while for the pupils with special needs it was $M=2.091$, therefore the significant statistical difference did not appear $(t=-0.708, g=132, P=0.480)$.

Other pupils showed a low degree of development of this social competence, as predicted. The hypothesis that the pupils with special needs show a lower level of development of social competence than other pupils was confirmed in the evaluation of this social competence, since both statements evoked a higher level of disagreement for the pupils with special needs than for other pupils. Within the frame of the given statements, a statistically significant difference was also revealed, regarding the assessment of the ability to recognize similarities and differences between the given groups from the perspective of the teachers.

The findings can be additionally corroborated with theoretical work, as it was stated that pupils with special needs face problems due to the lack of feelings of safety and acceptance, as well as a lack of self-control.

The statement Pupils show an equal attitude towards individuals who are of religion a different from their own was evaluated similarly by the teachers for the other the pupils $(M=1.971)$, as well as for the pupils with special needs $(M=1.969)$. The assumption of the homogeneity of variance $(\mathrm{F}=0.312, \mathrm{P}=0.577)$ was confirmed. There was no significant statistical difference between the evaluated groups in the assessment of these statements $(\mathrm{t}=0.014, \mathrm{~g}=131,2 \mathrm{P}=0.989)$.

The teachers evaluated the statement Pupils show an equal attitude towards individuals who originate from other countries, have different cultural habits and use their mother tongue in a similar way. As was the case with the preceding statement, the pupils with special needs again received a higher level of agreement $(\mathrm{M}=1.939)$ than other pupils $(\mathrm{M}=1.955)$. The assumption of the homogeneity of statement variance $(\mathrm{F}=0.000, \mathrm{P}=0.994)$ was thus confirmed. There was no significant statistical difference in the assessment of these statements, when comparing both evaluated groups $(\mathrm{t}=0.173, \mathrm{~g}=129,2 \mathrm{P}=0.836)$.

In the case of the statement Pupils show an equal attitude towards pupils with special needs, the teachers also granted a higher level of agreement to the pupils with special needs $(M=1.890)$. Other pupils were given $M=2.030$. The assumption of the homogeneity of variance $(\mathrm{F}=0.314, \mathrm{P}=0.576)$ was confirmed. There was no 
Table 7. Agreeing on the capability of accepting diversity and differences among pupils with special needs and other pupils

\begin{tabular}{|c|c|c|c|c|c|c|c|c|c|}
\hline \multirow{2}{*}{\multicolumn{2}{|c|}{$\begin{array}{c}\text { Acceptance of diversity } \\
\text { and differences }\end{array}$}} & \multirow[t]{2}{*}{$\mathbf{n}$} & \multirow[t]{2}{*}{ M } & \multirow[t]{2}{*}{$S$} & \multicolumn{2}{|c|}{$\begin{array}{l}\text { Levene's Test } \\
\text { for Equality } \\
\text { of Variances }\end{array}$} & \multicolumn{3}{|c|}{$\begin{array}{l}\text { T-test for Equality } \\
\text { of Means }\end{array}$} \\
\hline & & & & & F & $P$ & $t$ & g & $2 P$ \\
\hline \multirow{2}{*}{$\begin{array}{l}\text { Pupils show an equal } \\
\text { attitude towards } \\
\text { individuals who are } \\
\text { of a religion different } \\
\text { from their own }\end{array}$} & pupils & 68 & 1.971 & 0.546 & 0.312 & 0.577 & 0.014 & 131 & 0.989 \\
\hline & $\begin{array}{l}\text { pupils } \\
\text { with SEN }\end{array}$ & 65 & 1.969 & 0.585 & & & & & \\
\hline \multirow{2}{*}{$\begin{array}{l}\text { Pupils show an equal } \\
\text { attitude towards } \\
\text { individuals who } \\
\text { originate from other } \\
\text { countries, have } \\
\text { different cultural } \\
\text { habits and use their } \\
\text { mother tongue }\end{array}$} & pupils & 66 & 1.955 & 0.539 & 0.000 & 0.994 & 0.173 & 129 & 0.863 \\
\hline & $\begin{array}{l}\text { pupils } \\
\text { with SEN }\end{array}$ & 65 & 1.939 & 0.527 & & & & & \\
\hline \multirow{2}{*}{$\begin{array}{l}\text { Pupils show an equal } \\
\text { attitude towards pupils } \\
\text { with special needs. }\end{array}$} & pupils & 66 & 2.030 & 0.525 & 0.314 & 0.576 & 1.541 & 128 & 0.126 \\
\hline & $\begin{array}{l}\text { pupils } \\
\text { with SEN }\end{array}$ & 64 & 1.890 & 0.507 & & & & & \\
\hline
\end{tabular}

( $1=I$ strongly agree, $2=$ agree, $3=I$ strongly disagree)

significant statistical difference between the evaluated groups in the assessment of these statements $(\mathrm{t}=0.541, \mathrm{~g}=128,2 \mathrm{P}=0.126)$.

In assessing the acceptance of diversity and differences, the pupils with special needs, according to the teachers, show a higher level of development than other pupils, nevertheless there were no statistically significant differences between the two groups, while the assessments for both groups were relatively low, which was also predicted.

\section{Discussion}

The teachers estimated that other pupils show a low degree of development of individual social competences. They also estimated that the pupils with special needs show a lower level of development of social competences than other pupils in almost all issues (i.e. the identifying of their own feelings and empathy, as well 
as independence and responsible behavior within the group; the development of closeness, feelings of trust, security and belonging) except when evaluating the acceptance of diversity and difference, where the pupils with special needs showed a level of development similar to other pupils. The hypothesis stating that other pupils show a low level of development of social competences and the pupils with special needs even lower was therefore confirmed.

\section{Conclusion}

The results confirm that the area of social competences in elementary school still needs serious improvement. Social competences are extremely important for an individual, however pupils in Slovenian elementary school show a relatively low level of these skills, which could prove to be a worrying fact. In addition, pupils with special needs should receive more attention especially in areas where they are ahead when compared with their peers as this could contribute to a greater sense of their importance within society and raise their self-esteem, which represents the very foundation of social competence. According to Csóti (2009) the development of social, emotional and behavioral skills of children is essential if we want them to develop into mature adult individuals.

On the other hand, the society we live in today offers and ultimately requires the use of technology, multimedia and computers. This implies even greater individualization of the individual, which stands in contrast to social competence. Concerning this issue the following questions still need to be answered: To what extent, with whom and how do our pupils spend their leisure time?; What is the extent to which we could supervise our children and pupils, as parents and teachers, to encourage their independence?; Do they have the opportunity to demonstrate their accountability, do we trust them enough?

\section{References}

Csóti, M. (2009). Developing Children's Social, Emotional and Behavioural Skills. New York: Continuum International Publishing Group.

De Vaus, D.A. (2001) Surveys in Social Research. London: Routledge.

Ford, M.E. (1985). The concept of competence: Themes and variations. In: H.A. Marlowe, Jr. \& R.B. Weinberg (Eds.). Competence development (pp. 3-49). New York: Academic Press.

Ključne kompetence za vseživljenjsko učenje (2007). Evropski referenčni okvir. Retrieved 
8/2/2013 from http://ec.europa.eu/dgs/education_culture/publ/pdf/ll-learning/key comp_sl.pdf.

Magajna, L. (2008). Koncept dela Učne težave v osnovni šoli. Ljubljana: Zavod za šolstvo. Zakon o spremembah in dopolnitvah zakona o osnovni šoli (2007). Retrieved 8/2/2013 from http://www.uradni-list.si/1/objava.jsp?urlid=2007102\&stevilka=5073.

Oppenheimer, J.R. (1989). Atom and Void: Essays on Science and Community. New Jersey: Princeton University Press.

Warden, D. \& Christie, D. (2001). Spodbujanje socialnega vedenja. Ljubljana: Inštitut za psihologijo osebnosti. 